\title{
Deteksi Kualitas Telur Menggunakan Analisis Tekstur
}

\author{
Enny Itje Sela*1, M Ihsan ${ }^{2}$ \\ ${ }^{1}$ Teknik Informatika, Universitas Teknologi Yogyakarta, Indonesia \\ ${ }^{2}$ Teknik Informatika, STMIK AKAKOM, Yogyakarta, Indonesia

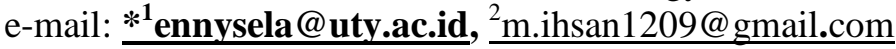

\begin{abstract}
Abstrak
Saat ini, deteksi kualitas telur dapat dilakukan berdasarkan pengamatan visual pada bagian kulit telur maupun bagian dalam telur. Cara ini memerlukan kemampuan visual yang baik pada pengamatnya. Mengingat telur dengan kualitas baik dan buruk mempunyai warna dan bentuk yang hampir mirip, maka jika menggunakan cara di atas, hasil deteksi relatif kurang valid. Penelitian ini mengkaji pemanfaatan pengolahan citra digital untuk deteksi kualitas telur menggunakan citra kulit telur.

Langkah-langkah untuk melakukan deteksi telur pada penelitian ini adalah preprocessing telur, pengambilan citra telur, seleksi RoI, ubah citra RoI dari citra berwarna menjadi citra grayscale, analisis fitur tekstur, pelatihan, dan pengujian. Beberapa fitur yang diekestrak adalah rerata intensitas, deviasi standar, skewness, energi, entropi, dan properti kehalusan atau smoothness. Fitur yang diperoeh selanjutnya digunakan pada pelatihan. Tahap pelatihan dan validasi menggunakan algoritme K-Means. Hasil pelatihan mendapatkan nilai cluster terbaik yang digunakan untuk melakukan validasi dan pengujian.

Hasil dari aplikasi ini mampu membantu pengguna untuk menentukan kualitas telur baik dan kualitas telur tidak baik. Nilai akurasi yang diperoleh saat pelatihan, validasi, dan pengujian berturut-turut adalah 70\%, 92\%, dan $85 \%$.
\end{abstract}

Kata kunci- analisis tekstur, energi, entropi, standar deviasi, K-Means, telur, skewness, smoothness

\begin{abstract}
Currently, egg quality detection can be performed based on visual observations on the eggshell as well as the inside of the egg. This method requires a good visual ability on the observer. Given eggs with good and bad quality have similar colors and shapes, so if using the above method, the detection results are relatively less valid. This study examines the utilization of digital image processing for the detection of egg quality using eggshell image.

The steps to perform egg detection in this study are egg preprocessing, egg image retrieval, RoI selection, change RoI image from color image to grayscale image, texture feature analysis, training, and testing. Some of the features that are exempted are the average intensity, standard deviation, skewness, energy, entropy, and smoothness properties. The subsequent features are used in the training. The training and validation stage uses the K-Means algorithm. The training results get the best cluster value used to perform validation and testing phases.

The results of this application is able to help the user to determine the quality of good eggs and egg quality is not good. Accuracy rates obtained during training, validation, and testing are $70 \%, 92 \%$, and $85 \%$, respectively.
\end{abstract}

Keywords- egg, energy, entrophy, K-Means, skewness, smoothness, standard deviation, texture analysis

Received May $3^{\text {rd }}, 2017 ;$ Revised July 29 ${ }^{\text {th }}, 2017$; Accepted July $29^{\text {th }}, 2017$ 


\section{PENDAHULUAN}

$\mathrm{T}_{\mathrm{s}}$ elur merupakan produk peternakan yang dapat membantu kecukupan gizi masyarakat. Pada sebutir telur mengandung zat-zat gizi yang mudah dicerna. Oleh karena itu, telur merupakan bahan pangan yang sangat baik bagi anak-anak. Selain itu, sebuah telur juga mengandung banyak protein dan mineral sehingga orang yang sedang sakit dianjurkan mengkonsumsi telur, untuk mempercepat proses kesembuhannya [1]. Secara umum, telur ayam merupakan telur yang paling sering dikonsumsi oleh masyarakat karena mudah didapatkan di pasaran dan harganya yang relatif terjangkau. Kebutuhan masyarakat terhadap telur ini semakin meningkat karena banyaknya permintaan pasar. Pada saat membeli telur, konsumen harus teliti dalam memilih telur karena kemungkinan telur yang dijual telah rusak atau mengalami penurunan kualitas. Hal ini disebabkan karena faktor waktu penyimpanan atau proses pengangkutan telur dari peternak ke toko. Oleh karena itu, proses untuk mendeteksi kualitas telur menjadi penting

Saat ini, cara yang digunakan untuk mengetahui kualitas dan kesegaran telur adalah melakukan pengamatan visual objek telur tersebut. Proses pengamatan dilakukan dengan menyinari telur ditempat gelap, kemudian menerawang isi telur tersebut menggunakan sinar matahari atau senter [2]. Cara lain yang bisa dilakukan adalah dengan melihat telur dari tampak luarnya berupa keadaan kulit, bentuk, ukuran, serta beratnya. Proses yang sama juga dilakukan oleh peternak dan penjual untuk menyeleksi kualitas telur ayam. Cara-cara tersebut memerlukan kecermatan yang baik sehingga hasil yang diperoleh untuk setiap pengamat pada sebuah objek telur, bisa berbeda.

Penggunaan citra sebagai media untuk deteksi maupun identifikasi objek telah banyak digunakan oleh beberapa peneliti. Pada penelitian $[3,4,5]$ memanfaatkan citra gigi untuk pemeriksaan osteoporosis. Penelitian [6] melakukan penelitian tingkat kematangan buah papaya menggunakan fitur warna merah (red), hijau (green), dan biru (blue) pada kulit buah. Adapun penelitian-penelitan yang memanfaatkan citra objek telur adalah [7, 8, 9]. Penelitian [7] melakukan penelitian telur ayam ras petelur menggunakan fitur statistik orde satu dan orde dua. Metode deteksinya menggunakan K-Nearest Neighbor (K-NN). Pada [8] mendeteksi kualitas telur ayam dengan metode action research template matching. Penelitian [9] mengembangkan sistem yang tidak hanya mampu mengklasifikasikan dua jenis telur yang berbeda, tetapi dapat mengklasifikasikan beberapa jenis telur yang hampir sama seperti telur ayam dan bebek, serta dapat menghitung jumlah dan memprediksi bobot atau berat telur-telur tersebut. Perbedaan tingkat akurasi dan hasil penelitian ini dapat disebabkan karena banyak hal, mulai dari proses capturing atau pengambilan gambar, perbedaan fitur yang digunakan untuk proses pengujian, jumlah data latih dan data uji yang digunakan serta tujuan dilakukannya penelitian tersebut.

Penelitian ini menyajikan cara untuk mendeteksi kualitas telur ayam berdasarkan citra kulit telur. Metode ekstraksi fitur yang digunakan adalah analisis tekstur, sedangkan proses deteksi kualitas telur, menggunakan metode $K$-Means. Algoritma K-Means memiliki kelebihan diantaranya adalah mudah diimplemenetasikan dan waktu pembelajaran yang cepat.

\section{METODE PENELITIAN}

\subsection{Bahan/Data dan Peralatan}

Bahan-bahan yang diperlukan untuk penelitian ini adalah 70 buah telur ayam petelur. Dari 70 data tersebut dibagi menjadi 50 data untuk pelatihan dan validasi (29 data telur berkualitas baik dan 21 telur berkualitas buruk) dan 20 data untuk pengujian (10 data telur dengan kualitas baik dan 10 data telur dengan kualitas buruk). Bagian telur yang diambil sebagai region of interest $(\mathrm{RoI})$ adalah kulit telur.

Instrumen atau alat-alat yang digunakan pada penelitian ini adalah kamera digital Fujifilm S2980, yang digunakan untuk mengambil citra objek berupa telur ayam. Citra yang diperoleh selanjutnya akan dideteksi untuk mengetahui apakah telur tersebut termasuk dalam

IJCCS Vol. 11, No. 2, July $2017: 199-208$ 
kelompok dengan kualitas baik atau kelompok dengan kualitas buruk. Adapun kriteria kualitas telur ayam yang baik adalah sebagai berikut $[1,2]$ : bentuk telur normal, kulit telur bersih, kulit telur rata, isi dalam telur tidak berbunyi jika digoncang, dan telur tidak catat atau retak.

\subsection{Rancangan Sistem dan Algoritma}

Secara umum, proses deteksi citra telur terbagi dalam tahap pelatihan, validasi, dan pengujian. Tahap pelatihan merupakan tahap untuk mencari model terbaik yang diperoleh berdasarkan data pelatihan citra. Validasi digunakan untuk mengetahui akurasi model yang dihasilkan pada tahap pelatihan. Tahap pengujian digunakan untuk mengetahui akurasi model pada data uji citra. Gambaran sistem deteksi telur dapat dilihat pada Gambar 2.

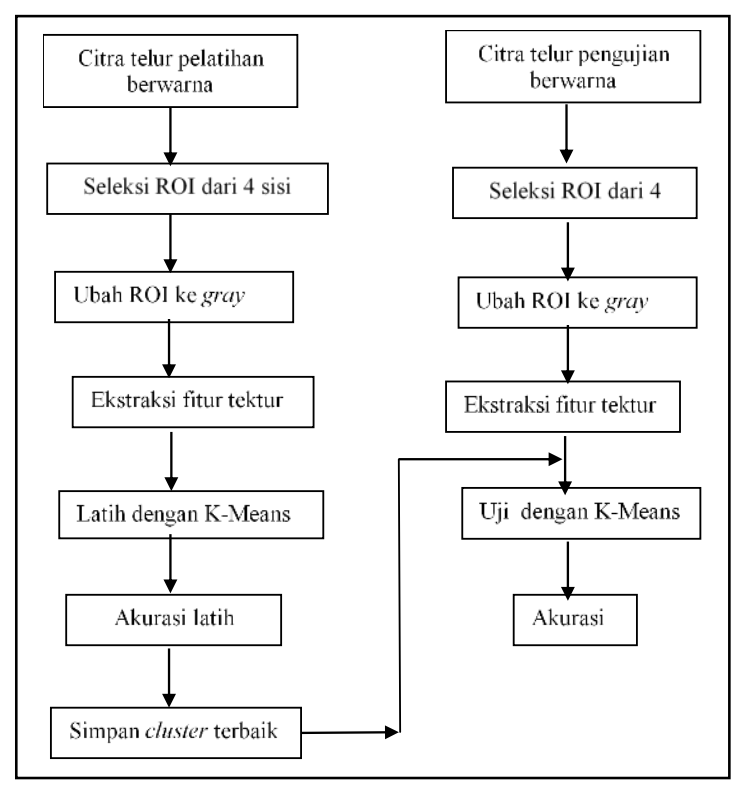

Gambar 1 Model deteksi kualitas telur

Masukan model sistem adalah citra telur dalam formal berwarna (full colour). Citra telur ini bisa diperoleh setelah telur melalui tahap pemrosesan awal (pre-processing). Proses ini dilakukan dengan cara membersihkan telur dari kotoran yang menempel pada kulit telur. Kotoran yang menempel dapat menyebabkan noise yang signifikan saat pengambilan citra.

Proses pengambilan citra telur dilakukan pada empat sisi telur yang berbeda sehingga satu telur akan diwakili dengan 4 citra sehingga banyaknya citra telur berwarna yang diperoleh pada tahap ini adalah 280 citra.

Untuk mendapatkan citra yang baik, pengambilan citra dilakukan berulang-ulang sampai didapatkan citra dengan noise minimum. Adapun prosedur pengambilan citra telur berwarna adalah sebegai berikut:

1) Pengambilan citra dilakukan pada pagi hari antara pukul 09.00 sampai dengan 10.00 .

2) Setting kamera dilakukan seragam: diafragma 6.4 iso otomatis dan speed otomatis

3) Kamera diletakkan tegak lurus terhadap objek telur dengan jarak $1 \mathrm{~m}$ agar didapatkan gambar keseluruhan telur

4) Background untuk objek telur berwarna putih agar objek telur terlihat jelas (Gambar 2)

Setelah memperoleh citra telur berwarna, langkah selanjutnya adalah melakukan akuisisi citra. Proses ini berguna untuk mendapatkan citra telur terbaik. Adapun kriteria untuk mendapatkan 
citra yang baik adalah gambar terlihat jelas (tidak kabur, gelap, atau kombinasi keduanya) dan tidak ada pantulan cahaya pada citra.

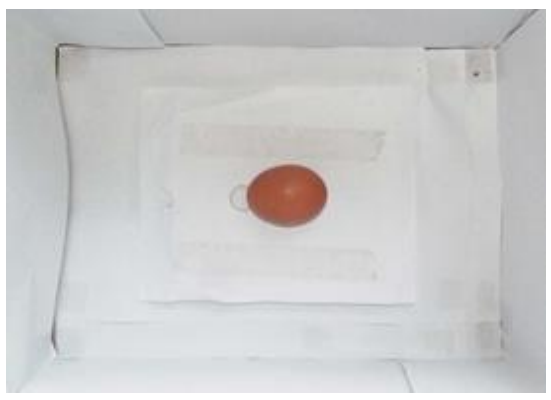

Gambar 2 Background untuk objek telur

Gangguan atau noise yang muncul saat pengambilan citra telur berwarna bisa disebabkan karena masalah peralatan, lingkungan, maupun human error. Tabel 1 menunjukkan contoh noise yang ditemukan pada proses akuisisi citra.

Tabel 1 Noise yang timbul saat pengambilan citra telur

\begin{tabular}{|l|l|}
\hline Citra Telur & $\begin{array}{l}\text { Kuncul noise berupa titik putih pada bagian tengah } \\
\text { telur karena ada pantulan cahaya ketika telur difoto. }\end{array}$ \\
\hline & $\begin{array}{l}\text { Noise pada bagian tepi telur yang difoto tidak fokus } \\
\text { (blur) atau tampak gelap (vignette) karena titik fokus } \\
\text { kamera hanya menjangkau bagian tengah dari telur }\end{array}$ \\
\hline
\end{tabular}

Setelah melakukan akusisi citra, proses selanjutnya adalah seleksi atau pengambilan RoI. Pada penelitian ini, ada 3 ukuran RoI yaitu 512 × 512 piksel, 342 × 342 piksel, dan 171 x 171 piksel. RoI diperoleh dengan melakukan proses croping atau pemotongan citra dengan menggunakan Adobe Photoshop Lightroom. Croping dilakukan dengan memperhatikan bagian dari telur tersebut yang kiranya mewakili kondisi sebenarnya dari telur yang diambil citranya, dengan noise yang paling minimum. Contoh gambar hasil croping telur dengan kualitas baik dan buruk ditunjukan pada Tabel 2. Dari proses croping didapatkan 280 data citra RoI . Citracitra ini disimpan dalam format jpg. 
Tabel 2 Contoh gambar telur dengan kualitas baik dan buruk

\begin{tabular}{|c|c|c|c|c|}
\hline $\begin{array}{c}\text { Nama } \\
\text { Klaster }\end{array}$ & $\begin{array}{c}\text { Gambar } \\
\text { Sisi depan }\end{array}$ & $\begin{array}{c}\text { Gambar } \\
\text { Sisi samping } \\
\text { Kiri }\end{array}$ & $\begin{array}{c}\text { Gambar } \\
\text { Sisi } \\
\text { Belakang }\end{array}$ & $\begin{array}{c}\text { Gambar } \\
\text { Sisi } \\
\text { Samping } \\
\text { Kanan }\end{array}$ \\
\hline Baik & & & & \\
\hline Buruk & & & & \\
& & & & \\
& & & & \\
\hline
\end{tabular}

Setelah RoI diperoleh, tahap berikutnya adalah mengubah format citra RoI. Pengubahan atau transformasi format ini diperlukan karena RoI mempunyai format berwarna full colour sedangkan untuk melakukan analisis tekstur, format citra harus citra abu-abu (grayscale). Hasil pengubahan format citra ini selanjutnya juga disimpan dalam file RoI grayscale. File-file tersebut selanjutnya digunakan untuk analisis tekstur.

\subsection{Analisis Tekstur}

Tekstur merupakan karakteristik intrinsik dari suatu citra yang terkait dengan tingkat kekasaran (roughness), granularitas (granulation), dan keteraturan (regularity) susunan struktural piksel. Analisis tekstur telah digunakan pada penelitian [10] untuk pengenalan spesies gulma dan [11] untuk mengenali motif kain tenun. Aspek tekstural dari sebuah citra dapat dimanfaatkan sebagai dasar dari segmentasi, klasifikasi, maupun interpretasi citra. Tekstur dapat didefinisikan sebagai fungsi dari variasi spasial intensitas piksel (nilai keabuan) dalam citra. Metode sederhana untuk mendapatkan tekstur adalah dengan mendasarkan pada histogram. Terdapat beberapa fitur-fitur yang dapat dikenal secara statistis melalui histogram.

Fitur pertama yang dihitung secara statistis adalah rerata intensitas kecerahan. Komponen fitur ini ditunjukan pada persamaan (1)

$$
\mathrm{m}=\sum_{\mathrm{i}=0}^{\mathrm{L}-1} \mathrm{i} \cdot \mathrm{p}(\mathrm{i})
$$

Dalam hal ini, i adalah aras keabuan pada citra $f$ dan $p(i)$ menyatakan probabilitas kemunculan menyatakan nilai aras keabuan tertinggi. Persamaan (1) akan menghasilkan rerata intensitas kecerahan.

Fitur kedua berupa devisasi standar. Formula perhitungannya ditunjukan pada persamaan (2)

$$
\sigma=\sqrt{\sum_{i=1}^{L-1}(i-m)^{2} p(i)}
$$

Dalam hal ini, Error! Reference source not found. dinamakan varians atau momen orde dua ternormalisasi karena p(i) merupakan fungsi peluang Fitur ini memberikan ukuran kekontrasan. Varabel I adalah aras keabuan pada citra dan variabel $\mathrm{m}$ adalah rerata intensitas. 
Fitur skewness merupakan ukuran ketidaksimetrisan terhadap rerata intensitas. Formula perhitungannya ditunjukan pada persamaan (3)

$$
\text { skewness }=\sum_{\mathrm{i}=1}^{\mathrm{L}-1}(\mathrm{i}-\mathrm{m})^{3} \mathrm{p}(\mathrm{i})
$$

Skewness sering disebut momen orde tiga ternormalisasi. Nilai negatif menyatakan bahwa distribusi kecerahan condong ke kiri terhadap rerata dan nilai positif menyatakan bahwa distribusi kecerahan condong ke kanan terhadap rerata.

Deskriptor energi adalah ukuran untuk menyatakan distribusi intensitas piksel terhadap jangkauan aras keabuan yang ditunjukkan pada persamaan (4)

$$
\text { energi }=\sum_{i=0}^{L-1}[p(i)]^{2}
$$

Citra seragam dengan satu nilai aras keabuan akan memiliki nilai energi maksimum, yaitu sebesar 1 (satu). Secara umum, citra dengan sedikit aras keabuan akan memiliki energi lebih tinggi daripada yang memiliki banyak nilai aras keabuan. Energi ini sering disebut dengan keseragaman.

Entropi mengindikasikan kompleksitas citra. Adapun rumus entropi ditunjukkan pada persamaan (5).

$$
\text { entropi }=-\sum_{i=0}^{\mathrm{L}-1} p(\mathrm{i}) \log _{2}(\mathrm{p}(\mathrm{i}))
$$

Semakin tinggi nilai entropi, semakin kompleks citra tersebut. Entropi merepresentasikan jumlah informasi yang terkandung di dalam sebaran data.

Properti smoothess/kehalusan biasa disertakan untuk mengukur tingkat kehalusan/kekasaran intensitas pada citra, dan formula ditunjukkan pada persamaan (6).

$$
R=1-\frac{1}{1+\sigma^{2}}
$$

Pada rumus di atas Error! Reference source not found. adalah deviasi standar. Nilai R rendah menunjukan bahwa citra memiliki intensitas kasar.

Proses analisis tekstur dilakukan pada file RoI yang berformat grayscale. Hasil analisis tektur berupa matriks fitur pelatihan berukuran $50 \times 24$ dan matriks fitur pengujian berukuran $20 \times 24$ File fitur ini disimpan dalam tipe txt, yang selanjutnya digunakan pada pelatihan, validasi, dan pengujian.

\subsection{Deteksi telur}

Proses deteksi dilakukan melalui pelatihan dan pengujian dengan metode $K$-Means dengan memanfaatkan fitur hasil analisis tekstur. Adapun algoritma pelatihan data secara lengkap adalah sebagai berikut.

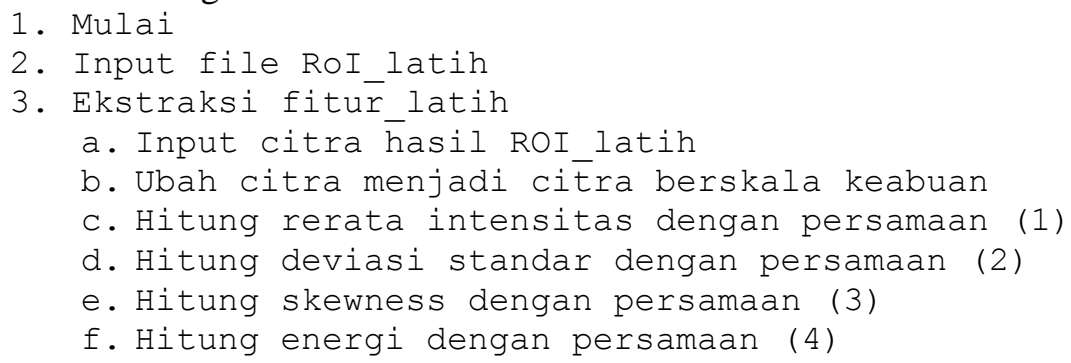




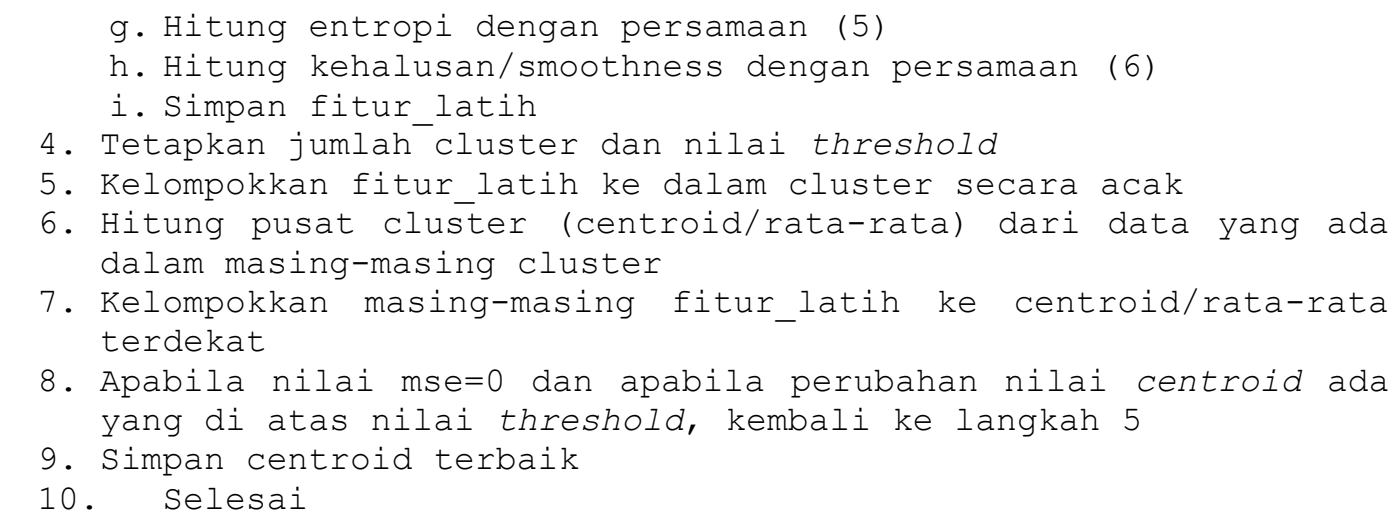

Sedangkan algoritma validasi dan pengujian data adalah sebagai berikut:

1. Mulai

2. Input citra RoI

3. Lakukan ekstraksi ciri tekstur data uji

a. Input citra hasil ROI latih

b. Ubah citra menjadi cit̄ra berskala keabuan

c. Hitung rerata intensitas dengan persamaan (1)

d. Hitung deviasi standar dengan persamaan (2)

e. Hitung skewness dengan persamaan (3)

f. Hitung energi dengan persamaan (4)

g. Hitung entropi dengan persamaan (5)

h. Hitung kehalusan/smoothness dengan persamaan (6)

i. Simpan ciri uji

4. Panggil centroid terbaik hasil pelatihan data latih

5. Hitung jarak ciri uji ke centroid terbaik

6. Bandingkan jarak $\bar{d} 1$ (centroid 1) dengan d2 (centroid 2)

7. Jika jarak d1<d2 maka data masuk ke cluster 1 yaitu baik, jika d1>d2 maka data masuk ke cluster 2 yaitu buruk

8. Tampilkan hasil

9. Selesai

\section{HASIL DAN PEMBAHASAN}

\subsection{Hasil}

Berikut disajikan hasil implementasi perangkat lunak sistem deteksi telur yang telah dikembangkan. Proses dan hasil menu pelatihan sistem tersebut dapat dilihat pada Gambar 3, dengan menampilkan inisialisasi cluster awal dan nilai cluster terbaik hasil pelatihan. Selain itu, sistem juga memberikan informasi mengenai error ratio yang dapat digunakan untuk menentukan nilai akurasi. Pelatihan dilakukan dengan menggunakan beberapa nilai parameter yang berbeda. Hal ini dimaksudkan untuk mencari nilai akurasi terbaik dengan jumlah iterasi minimal. Parameter pertama adalah ukuran citra. Pada parameter ini ukuran citra yang diuji adalah 512 × 512 piksel, 342 x 342 piksel, dan 171 x 171 piksel. Parameter kedua adalah threshold dengan nilai yang diuji adalah 0,$0001 ; 0,001 ; 0,01$ dan 0,1 .

Tabel 3 menunjukkan hasil pelatihan dengan menggunakan paramater-parameter tersebut. Persentase akurasi tertinggi dicapai pada nilai sebesar $70 \%$, yaitu pada pelatihan ke $1,5,6,7$, dan 8. Adapun minimal jumlah iterasi pelatihan yang bisa memperoleh nilai akurasi $70 \%$ adalah 20 (pada pelatihan ke-5). Dengan demikian, model terbaik hasil pelatihan dicapai pada parameter ukuran RoI berukuran 342 x 342 pixel dan nilai threshold sebesar 0,0001. Adapun cara menentukan tingkat akurasi sebesar $70 \%$ dihitung menggunakan tabel error ratio (Tabel 4). 


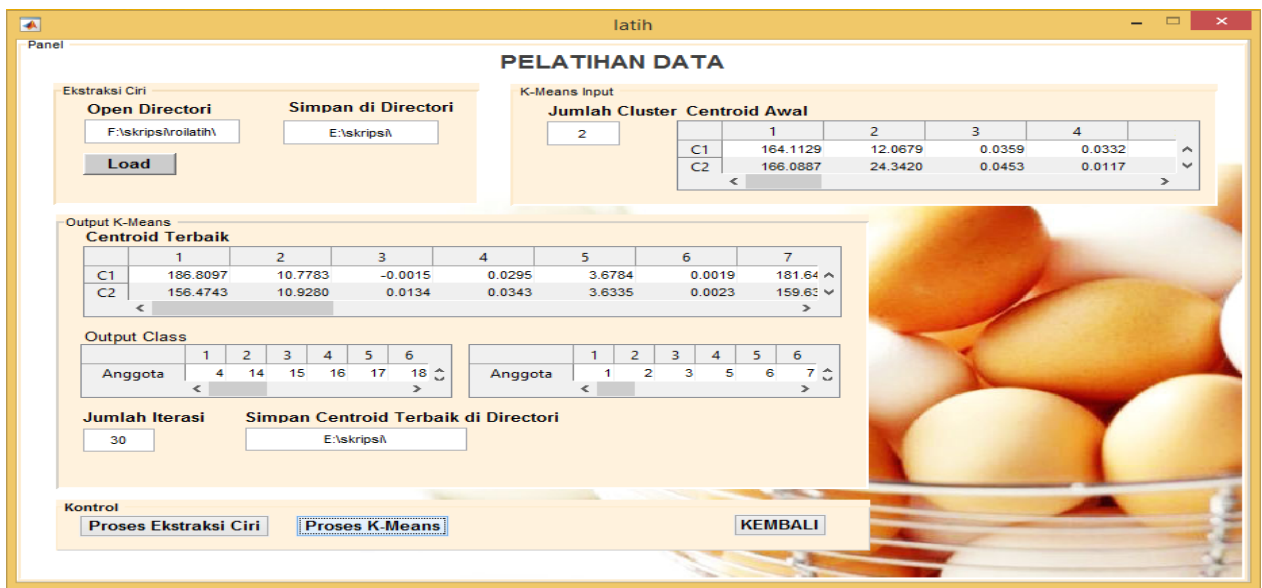

Gambar 3 Pelatihan

Tabel 3 Hasil pelatihan

\begin{tabular}{|l|l|r|r|r|}
\hline No & Ukuran Citra & Nilai Treshold & Jumlah Iterasi & \multicolumn{2}{l|}{$\begin{array}{l}\text { Akurasi } \\
\text { Pelatihan }\end{array}$} \\
\hline 1 & $512 \times 512$ pixel & 0,0001 & 29 & $70 \%$ \\
\hline 2 & & 0,001 & 21 & $68 \%$ \\
\hline 3 & & 0,01 & 21 & $68 \%$ \\
\hline 4 & & 0,1 & 29 & $68 \%$ \\
\hline 5 & $342 \times 342$ pixel & 0,0001 & 20 & $70 \%$ \\
\hline 6 & & 0,001 & 30 & $70 \%$ \\
\hline 7 & & 0,01 & 30 & $70 \%$ \\
\hline 8 & & 0,1 & 30 & $70 \%$ \\
\hline 9 & $171 \times 171$ pixel & 0,0001 & 25 & $64 \%$ \\
\hline 10 & & 0,001 & 25 & $64 \%$ \\
\hline 11 & & 0,01 & 25 & $64 \%$ \\
\hline 12 & & 0,1 & 25 & $64 \%$ \\
\hline
\end{tabular}

Tabel 4. Error ratio pelatihan

\begin{tabular}{|l|r|r|rr|}
\hline Kualitas telur & Cluster 1 & Cluster 2 & Hasil Terbaik & \\
\hline Baik & 17 valid & 3 valid & 17 \\
\hline Buruk & 12 valid & 18 valid & 18 \\
\hline
\end{tabular}

Berdasarkan hasil pada Tabel 4, cluster 1 lebih mengindikasikan sebagai kelompok telur dengan kualitas baik, sedangkan cluster 2 lebih mengindikasikan pada kelompok telur dengan kualitas buruk. Total data yang dapat dinyatakan valid oleh sistem sebanyak 35 data dari 50 data. Dengan demikian, nilai akurasi pelatihan yang dihasilkan adalah $70 \%$. Selain menghitung akurasi, pada pelatihan juga menyimpan masing-masing nilai akhir cluster, yang selanjutnya digunakan sebagai validasi dan pengujian data baru.

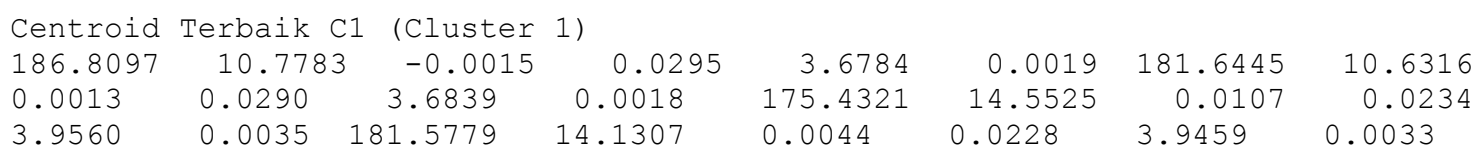




\begin{tabular}{|c|c|c|c|c|c|c|c|}
\hline 156.4743 & 10.9280 & 0.0134 & 0.0343 & 3.6335 & 0.0023 & 159.6332 & 10.6475 \\
\hline-0.0110 & 0.0358 & 3.5894 & 0.0024 & 157.3802 & 15.3661 & -0.0197 & 0.0246 \\
\hline 3.9466 & 0.0047 & 159.1121 & 12.9247 & 0.0046 & 0.0291 & 3.8001 & 0.0032 \\
\hline
\end{tabular}

Pada proses validasi, data yang digunakan sama dengan data pelatihan dan persentase nilai akurasi yang diperoleh adalah $92 \%$.

Pada pengujian data baru mempunyai mekanisme yang sama dengan proses validasi. Sistem ini bisa dilakukan dengan 2 cara yaitu uji untuk sebuah telur saja (Gambar 4) atau diuji untuk beberapa telur sekaligus (Gambar 5). Hasil pengujian terbaik pada 20 data diperoleh nilai akurasi sebesar $85 \%$

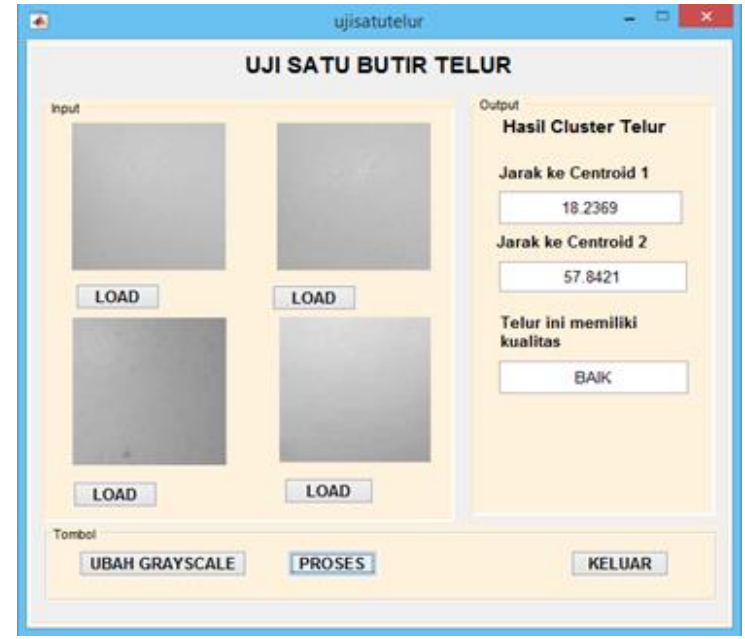

Gambar 4 Uji pada sebuah telur

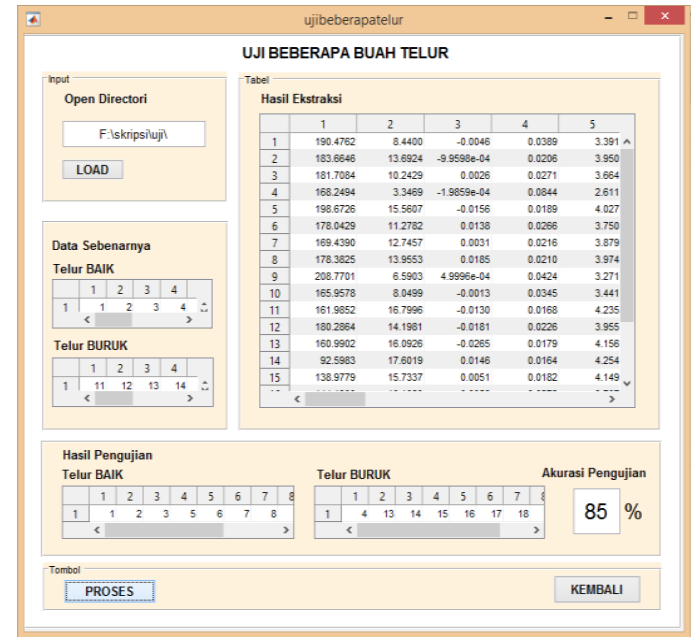

Gambar 5 Uji pada beberapa telur

\subsection{Pembahasan}

Berdasarkan hasil penelitian sebelumnya, menggunakan objek telur memiliki rata-rata akurasi yang cukup bagus. Pada penelitian [7] yang memiliki objek telur ayam ras dengan menggunakan metode K-NN mempunyai tingkat akurasi 88,89\%, masih lebih baik daripada penelitian yang diusulkan dengan tingkat akurasi sebesar $85 \%$. Pada penelitian [8] yang menggunakan objek telur ayam lehor dengan 8 sampling dan 3 template mampu menghasilkan akurasi sebesar $62,5 \%$, hal ini dikarenakan pada proses pengujian masih mengunakan tools dan template yang digunakan relatif sedikit. Pada penelitian [9] dengan objek telur ayam dan telur burung puyuh dengan metode klasifikasinya menggunakan Connected Component Analysis menghasilkan tingkat akurasi sebesar $100 \%$.

Penelitian ini memiliki kelemahan antara lain masih terdapat banyak noise dalam akuisisi citra sehingga berpengaruh dalam proses pelatihan, keterbatasan banyaknya data sampel, dan hasil akurasi pada klaster masih belum lebih baik disbanding penelitian sebelumnya.

\section{KESIMPULAN}

Berdasarkan pengujian aplikasi dengan beberapa parameter diperoleh kesimpulan sebagai berikut:

1) Model terbaik dihasilkan pada ukuran RoI citra 342 x 342 piksel dan nilai threshold 0,0001 .

2) Nilai akurasi yang diperoleh tahap pelatihan, validasi, dan pengujian adalah $70 \%, 85 \%$, dan $92 \%$ 


\section{DAFTAR PUSTAKA}

[1] T. Yuwanta, Telur dan Kualitas Telur, 2010, Gadjah Mada University Press, Yogyakarta.

[2] Soeparno, Dasar Teknologi Hasil Ternak, 2011, Gadjah Mada University Press, Yogyakarta.

[3] EI. Sela dan R. Widyaningrum, R., 2015, "Osteoporosis Detection Using Important Shape-Based Features of The Porous Trabecular Bone On The Dental X-Ray Images", Interl. Journal of Advanced Computer Science and Apllications (IJACSA), Vol 11 No 6. http://thesai.org/Publications/ViewPaper?Volume $=6 \&$ Issue $=9 \&$ Code $=I J A C S A \&$ Seria $\underline{1 \mathrm{No}=33}$ [accessed: 10 -june-2017]

[4] EI. Sela, S. Hartati, A. Harjoko, R. Wardoyo, M. Mudjosemedi, "Features Selection Of The Combination Of Porous Trabecular With Anthropometic Features For Osteoporosis Screening", Interl. Journal Electrical and Computer Engineering (IJECE), Vol. $\quad 5 \quad$ No $1, \quad 2015 . \quad$ Available: http://iaesjournal.com/online/index.php/IJECE/article/view/6922. [Accessed: 10-june2017]

[5] EI. Sela, S. Hartati, A. Harjoko, R. Wardoyo, M. Mudjosemedi., "Segmentation On Periapical Dental X-Ray For Osteoporosis Screening", International Journal of Advanced Computer Sciences and Applications (IJACSA), Vol 4 No 7, 2013. Available:

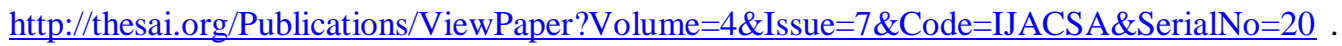
[Accessed: 10-june-2017]

[6] H. Prahara, EI. Sela, "Identifikasi Tingkat Kematangan Buah Pepaya Menggunakan Jaringan Syaraf Tiruan Learning Vector Quantization”, Seminar Nasional Riset Teknologi Informasi (SRITI) 2016, STMIK AKAKOM Yogyakarta. Available: http://sritiakakom.ac.id/prosiding/TINGKAT KEMATANGAN BUAH PEPAYA DENGAN JARINGAN SYARAF LVQ.pdf . [Accessed: 10-june-2017]

[7] Trisnaningtyas, P.R., Maimunah, "Klasifikasi Mutu Telur Berdasarkan Kebersihan Kerabang Telur Menggunakan K-Nearest Neighbor", 2015, Universitas Islam "45", Bekasi. Available: http://knif2015.stei.itb.ac.id/wp-content/uploads/2015/11/KNIF2015-70-Klasifikasi-Mutu-Telur-Berdasarkan-Kebersihan-Kerabang-TelurMenggunakan-K-Nearest-Neighbor.pdf. [Accessed: 10-june-2017]

[8] A. Sugiharto, "Pemodelan Deteksi Kualitas Telur Berbasis Citra", 2016, Skripsi STMIK AMIKOM, Yogyakarta. Available: ejournal.amikompurwokerto.ac.id/index.php/telematika/article/view/411. [Accessed: 10-june2017]

[9] I. Ruslianto, "Klasifikasi Telur Ayam dan Telur Burung Puyuh Menggunakan Metode Connected Component Analysis", 2013, Skripsi, STMIK Pontianak, Kalimantan Barat. Available: http://www.sisfotenika.stmikpontianak.ac.id/index.php/ST/article/view/46. [Accessed: 10-june-2017]

[10] Herman and A. Harjoko, "Pengenalan Spesies Gulma Berdasarkan Bentuk dan Tekstur Daun Menggunakan Jaringan Syaraf Tiruan", IJCCS Vol. 9 No.2, 2015, ISSN: 1978-1520. Available: https://journal.ugm.ac.id/ijccs/article/view/7549. [Accessed: 10-june-2017]

[11] NM. Setiohardjo, A. Harjoko, "Analisis Tekstur untuk Klasifikasi Motif Kain (Studi Kasus Kain Tenun Nusa Tenggara Timur)", IJCCS Vol 8 No 2, 2014, ISSN: 19781520. Available: https://journal.ugm.ac.id/ijccs/article/view/6545. [Accessed: 10-june2017] 